\title{
DEVELOPING ARCTIC TOURISM AMID INTENSIFYING INTERNATIONAL AND INTERREGIONAL COOPERATION
}

\section{SVETLANA ZHURA, IRINA ERSHOVA, IVAN SAVELEV, ELENA BOGDANOVA, ALEXANDER TETERIN \& NADEZHDA CHERTOVA}

Northern (Arctic) Federal University Named After M. V. Lomonosov, Arkhangelsk, Russia

\begin{abstract}
With increasing international and interregional cooperation in the Arctic zone, development of Arctic tourism is of great importance for the positioning of countries, including Russia, on the global stage, and is one of the ways to facilitate the sustainable economic growth of the region. Arctic tourism is determined as a kind of tourism allocated within the boundaries of the Arctic, which is defined as the northern region of the Earth comprised of the Arctic Ocean with its seas, bays, straits, archipelagos, and single islands, as well as of the northern coasts of Eurasia and North America. Alternatively, Arctic tourism can be defined with regard to the national component. The article intends to express the opinion suggesting treating Arctic tourism as a freestanding kind of tourism. The authors single out specific features and principles of the Arctic tourism. Implementation of these principles shall ensure proper organization level of travel across the vast Arctic territories along with the preservation of unique natural resources of the Arctic. The authors then conclude that it is currently necessary to bring the basics of the Arctic tourism under the regulatory control in order to furnish all parties directly or indirectly involved in the tourist activities with a correct general understanding of the term in question.

KEYWORDS: Arctic Tourism, Arctic Territories, Arctic Tourism Regulation, Regional Development, Tour Package
\end{abstract}

Received: May 28, 2020; Accepted: Jun 18, 2020; Published: Jul 24, 2020; Paper Id.: IJMPERDJUN2020436

\section{INTRODUCTION}

Tourism serves as one of the crucial elements of a personality development contributing to the satisfaction of various spiritual needs and playing an important role in resolving social issues, while creating new jobs, increasing employment and improving public well-being at the same time. In addition to that, tourism is one of the most important areas to influence the economic growth and socioeconomic development of the entire country, including such sectors as transport, food, construction, and others.

In circumpolar countries, the Russian Federation included, of long-term legal, social, economic and political importance is the development of Arctic tourism, which has gained significant popularity in the recent years, thus increasing supply and demand in the market of tourism and related services.

Recognition of Arctic tourism as an independent kind of tourism and identification of its specific principles is based upon certain peculiarities, which must be explored in order to provide a comprehensive justification for further development of this tourist destination both in the Russian Federation and other Arctic states.

This research is relevant mainly due to the fact that the necessity of development of the Arctic territories, specifically regarding cooperation between Arctic and non-Arctic states in the field of science and technology, ignites particular interest in the Arctic tourism expansion as a trend of international and interdisciplinary studies. 


\section{LITERATURE REVIEW}

Many Russian and foreign researchers are concerned with the issues of Arctic tourism development. Proceeding from the general definition of tourism, it is essential to note that Arctic tourism is a kind of tourism allocated within the boundaries of the Arctic, which is described as the northern region of the Earth comprised of the Arctic Ocean with its seas, bays, straits, archipelagos and single islands, as well as of the northern coasts of Eurasia and North America (Geographic Encyclopedia, n.d.).

One can also define Arctic tourism as internal and international tourism in the Arctic and a promising economic sector of the Arctic countries, particularly for those territorial units of these countries located immediately in the Arctic latitudes (Lukin, 2016). Researchers report that in the recent years Arctic tourism has become very popular among Chinese citizens. The number of Chinese tourists traveling to the lands of the Northern Lights has increased by $400 \%$ in 2017. Russian Arctic has been one of the most popular Arctic regions (Fes, 2018).

Researchers put special emphasis upon the correlation between Arctic tourism development and planet warming kindling interest in iceberg tourism (Eagan, 2019). At the same time, researchers express concern over the fact that tourism growth for the sake of economic development (resulting in demand for larger infrastructure) could lead to environmental degradation and adversely impact small communities dwelling in the Arctic areas (Maher et al., 2014).

However, the studies conducted are definite about the fact that the implementation of touristic projects, which imply the establishment of Arctic recreation areas, would be promotive of the proper unlocking of the northern territories' tourism potential and could become an innovative impetus for their development (Orlova, 2017).

Thus, the study of scientific literature allows for the conclusion that the concept of Arctic tourism is of complex nature, and it is necessary to resort to the interdisciplinary approach in order to look into the issues of its development.

\section{METHODS}

Methodological framework of this research involves general (analysis, synthesis, deduction, induction) and specific (formal and comparative) legal methods of scientific cognition. Special emphasis in this paper is made on the legalistic method, which was used to analyze Russian and international case law regarding the conceptual field of Arctic tourism.

It shall be noted that the entirety of Arctic territories, i.e. the Arctic region, is formed by such states as the Russian Federation, Denmark, Iceland, Canada, Norway, the USA, Finland, and Sweden, which means that the term Arctic region shall be construed in a broader sense of these eight Arctic countries.

As far as the organization of Arctic tourism exclusively in the Russian Federation is concerned, the term Arctic region shall be defined narrowly and equated to the statutory definition of the Russian Federation Arctic zone fully or partly comprising the territories of the Sakha Republic (Yakutia), Murmansk and Arkhangelsk Regions, Krasnoyarsk Region, Nenets, Yamalo-Nenets and Chukotka Autonomous Areas outlined by the decision of the USSR Council of Ministers State Commission for the Arctic on April 22, 1989, as well as lands and islands specified in the Resolution of the USSR Central Executive Committee Presidium as of April 15, 1926, titled "On the announcement of the lands and islands located in the Arctic Ocean the USSR territories", along with internal sea waters, territorial sea, exclusive economic zone and continental shelf of the Russian Federation adjacent to the above mentioned territories, within which boundaries 
Russia has sovereign rights and jurisdiction in accordance with the international law (in compliance with the Russian Federation President Decree No. 296 as of May 02, 2014).

It is essential to identify the points allowing to treat Arctic tourism as a freestanding kind of tourism:

- Particular image of the Arctic territory attracting tourists with its extreme natural and weather conditions, variety of mineral, raw material and other resources, as well as a large amount of settlements inhabited by smallnumbered indigenous peoples;

- Uniqueness of natural, cultural and historical potential in the circumpolar space, including rich cultural heritage, natural reserves and aquatic areas of the northern seas;

- Satisfaction of spiritual and other needs of a person willing to receive an exclusive tourism product.

Thus, specific features of Arctic tourism are based upon the availability of a distinctive tourism product.

At the national level, in each of the eight Arctic countries there are competent authorities to regulate the issues related to the Arctic region development within state borders by means of adopting Arctic strategies reflecting contemporary view on the Arctic.

For instance, such statutory instruments as

- Fundamentals of the Russian Federation State Policy in the Arctic until 2020 and for a Further Perspective (2009) and Development Strategy of the Arctic Zone of the Russian Federation and National Security for the Period up to 2020 (2013) have been adopted. The content of these instruments implies that the Russian Federation is on its way towards establishment of the national Arctic policy underpinned by the principles of openness, cooperation and awareness of the Arctic zone exploration results with an aim to reinforce Russia's positive image in order to develop Arctic tourism.

- US Homeland Security Directive (Arctic Region Policy, 2009);

- Canada's Northern Strategy: Our North, Our Heritage, Our Future (2009);

- Finland's Strategy for the Arctic Region (2013);

- Sweden's Arctic strategy (2011);

- Norway’s Arctic Strategy (2006);

- Kingdom of Denmark Strategy for the Arctic 2011-2020 (2011);

- Iceland's policy statement titled Iceland 2020. Knowledge, sustainability and welfare (2011).

Analysis of the above mentioned Arctic strategies demonstrates that each of them treats tourism as one of the promising trends in the circumpolar countries' national policies.

Taking into account that the Arctic is described as a single natural object, albeit split between the states, Arctic tourism shall develop in a similar manner in all circumpolar countries.

Thus, common views towards the importance of tourism along with similar climate, biological and other peculiarities of the Arctic regions under different jurisdictions allow for the conclusion that the development of Arctic 
tourism is not an exclusively national field of interest. Hence, the issues of the Arctic development should be discussed internationally, and policies of different states should not contradict each other.

For the purposes of harmonization of relations in the field of tourism in the Arctic, the World Wildlife Fund proposed ten basic provisions (principles) of Arctic tourism (Linking tourism and conservation in the Arctic, 2016).

These Arctic tourism principles are formulated as instructions and can be divided in separate topical clusters.

The first cluster includes provisions aimed at environmental protection:

- Make tourism and conservation compatible;

- Support the preservation of wilderness and biodiversity;

- Use natural resources in a sustainable way;

- Minimize consumption, waste and pollution.

For instance, in accordance with the provisions, tourism companies and individual tourists shall act in such a way as to exclude any negative impact on the environment, irrespective of whether the product of Arctic tourism is utilized inside or outside the cities. In any case, tourism activities imply utilization of appropriate resources, especially considering the fact that they take place for the purposes of health improvement, recreation, development of learning, physical culture and sports, as well as some other goals excluding those intended to generate income in the country of temporary residence. In this regard, it is essential to put special emphasis on the measures taken to protect the vast but sparsely populated Arctic territories, where tourist resources (natural objects) remain intact.

The following cluster of principles expects tourists to show respect to the local traditions:

- Respect local cultures and lifestyles;

- Respect historic and scientific sites.

It is crucial to understand that these principles are necessary to follow both when traveling internationally (i.e. visiting a foreign state), and within the borders of one's own country. For instance, when using a tourism product in Russia (The Constitution of the Russian Federation, 1993), Norway (The Constitution of the Kingdom of Norway, 1814), and Finland (The Constitution of Finland, 1999), one shall respect the interests of indigenous small-numbered peoples dwelling in certain areas.

The third cluster contains recommendations to develop beneficial consequences both for the receiving and the visiting party when managing Arctic tourism:

- Local communities should benefit from tourism;

- Trained staffs are the key to responsible tourism.

The fourth cluster includes the principles, which, if followed, can help tourists to avoid emergency situations or unforeseen complications:

- Make your trip an opportunity to learn;

- Follow safety rules. 
The principles above serve as guidelines only. However, their main ideas lie at the heart of numerous statutory instruments adopted in the circumpolar countries, particularly those in the field of environmental protection.

Thus, appealing nature of the Arctic serves as a favorable prerequisite for recreational exploration of its territory, while tackling socioeconomic and ecological challenges of the Arctic region as a whole, e.g. by means of rational restriction of natural resources exploitation, expanding the network of natural reserves, developing folk crafts, opening cultural centers and creating new jobs.

The entirety of specific features has its impact on the content of a tourism product, and can quite possibly shape the specific status of a person experiencing the Arctic. With due regard to the fact that such terms as tourism product, tourist as well as a closely related tourism product promotion and marketing, are recognized as the main categories of tourism legislation, it shall be concluded that adoption of certain regulations governing the legal foundations of Arctic tourism would be a positive event, since it would emphasize the priority of this kind of tourism at both national and international levels.

Basically, the necessity to bring the basics of Arctic tourism under regulatory control has emerged in order to furnish all parties directly or indirectly involved in the tourist activities with a correct general understanding of the term in question.

In summary, Arctic tourism supported by the state is gaining popularity among tourists, resulting in increased demand and, subsequently, supply on behalf of tour operators and agencies.

\section{RESULTS}

From the authors' point of view, tourism products shall be promoted not only by the tour companies, but also by the territorial authorities in order to evolve and unlock the Arctic tourism potential.

For the purposes of tourism product promotion it is necessary to provide for the comprehensive set of measures aimed at its marketing and sales, i.e. advertising, participation in field-specific exhibitions, opening tourism information centers, publishing brochures, leaflets, etc.

The process of promotion of any Arctic tourism product on the territory of the Arctic region faces certain challenges, or tourism deterrents.

Specifically, in the Russian Federation one of the main challenges for Arctic tourism organizers is underdeveloped transport and logistics infrastructure of the regions. For instance, only 1,807 out of 3,951 settlements in the Arkhangelsk Region have paved roads. This ratio is 39 to 145 and 5 to 35 in the Murmansk Region and the Nenets Autonomous Area, correspondingly. Due to such massive underdevelopment of land communications, marine and inland water transport accounts for the major traffic load, although the ships are severely worn and infrastructure of ports and berths is long outdated. A possibility to use several types of transport in parallel shall not be overlooked. For example, sea voyage, like the one to Franz Josef Land, is the most popular way of getting tourists around the Arctic, and it is closely related to the necessity of using air transport, namely for the prevention of emergencies.

Another deterrent on the way of Arctic tourism stems from the above mentioned challenge - high cost of an Arctic tour organization and implementation. In view of current medical indications, a tourist might need urgent evacuation from the ship, and in case it could not be done by air, the ship would have to change its course and head for the mainland. 
Considering high expenses for an Arctic tour organization, deviation from the route would cause damage not only to the tourists and tour operators (agencies), but also to the regional budget and to the state as a whole. In case the travel fails to follow the scheduled program, it undermines the tourist's experience of the tour organization, decrease the profit of business entities involved, and adversely impacts the development of national and international tourism.

In order to eliminate this deterrent, and to promote Arctic tourism products as attractive and affordable, it is necessary to create a special purpose cruise fleet and improve the inland infrastructure.

Among other challenges in the field of Arctic tourism promotion one can distinguish ecological threats of anthropogenic (pollution on the territory of Novaya Zemlya) or natural origin (harsh climate conditions, treacherous weather, winds), which have detrimental effect on the environment and the duration of recreation period (up to 3-4 months) making tourists choose other destinations (southern seas, European tours).

It is possible to resolve the said issue as follows: on the one hand, more severe punishments shall be adopted for exerting negative anthropogenic impact on the Arctic nature; and on the other hand, Arctic tourism shall be promoted, with tours organized in such a way as to use the full potential of the recreation period (increasing the number of cruise travels, providing more services, developing road and hotel infrastructure).

It shall also be noted that despite Arctic tourism development over the recent years, a lot of people are still unaware of the tourism potential in the Arctic. Interestingly, a number of studies conducted by the National Tourist Union have shown that Russians do not associate the Arctic region with a vacation spot, and in accordance with the findings of a sociological research among 100 people aged 20 to 65, only 32\% of respondents said they wished to visit the Arctic. By contrast, the vast majority of foreign tourists coming to the Russian Arctic are those aged from 50 to 70, who are attracted by exoticism and uniqueness of the natural landscape. The lack of interest in the development of internal Arctic tourism among Russian citizens is expressed in the following way: $40 \%$ of respondents would go beyond the Polar Circle because of extreme weather conditions; $16 \%$ of respondents said they were not against visiting the Russian Arctic, but they did not know what they could do there; and 12\% of respondents are deterred by the high tour price (National Tourist Union, 2018).

The set of problems hindering the development of tourism in the Arctic involves quality of upbringing and educational background of those participating in tourist relationships. For instance, low levels of general, legal and ecological culture in tourists, tour operators and tour agents has an enormous negative impact on the state of resources in the Arctic region (pollution by production and consumer wastes, illegal hunting and fishing). Unfortunately, the existing system of personnel training does not allow training specialists completely conforming to the current changes and needs of certain tourism industry segments. Arctic tourism as a unique branch of tourist activities requires specialized theoretical and practical training. The real challenge resides in the fact that organization of Arctic tours calls for the necessity of complex training, which would include: 1) knowledge of civil, international and others branches of law; 2) knowledge about the region's history and development; 3) skills in providing emergency medical aid in harsh conditions of the Arctic.

Thus, finding solutions to the problems discussed is one of the priorities in furtherance of development and promotion of Arctic tourism products both in the national and international markets. These activities will positively impact tourists, who will get the opportunity to experience new tours, and business entities, which will be able to implement their projects in the field of tourism. The state and its particular regions will also benefit. 


\section{DISCUSSION}

With increasing international and interregional cooperation in the Arctic zone, development of Arctic tourism is of great importance for the positioning of countries, including Russia, on the global stage, and is one of the ways to facilitate sustainable economic growth of the region and to level out the standards of living in the areas of traditional lifestyle and in the new settlements formed around extractive industry enterprises. Tourism in the Arctic is a relatively recent phenomenon, which is picking up its pace and has certain specifics due to extraordinary natural and infrastructural conditions, and thus requiring efficient government regulation, support and control intended to guide and speed up its development and resolve a number of issues, which are impossible to overcome with efforts of tour operators and local initiatives only.

However, of utmost importance is not the amount of measures proposed and applied, but their consistent, careful and wellconsidered implementation along with timely adjustment. Tourism shall hold a firm place in the policies adopted in the subarctic regions, including the Russian Arctic. This is the only way to resolve the issues related to infrastructure and tourism, and make the proposed measures effective and successful.

The tourism industry faces a task of creating a cost efficient and sustainable model of its own existence and development, which could take into account the interests of all stakeholders: international organizations and states, indigenous peoples and long-term residents, local communities and business entities.

\section{CONCLUSIONS}

Summarizing the research into Arctic tourism as a developing branch of tourism the following conclusions shall be emphasized:

Unlocking the Arctic region's tourism potential while rationally using its resources will allow to:

- Facilitate multifaceted development of the Arctic territories by means of strengthening their appeal for investors and for a wider circle of domestic and foreign consumers;

- Shape favorable environment for tourism development;

- Reinforce competitive advantages of the Arctic tourist destinations;

- Create new innovative tourism products for different consumer classes;

- Work towards successful socioeconomic growth of the Arctic territories and improve well-being of the population;

- $\quad$ Promote respect for the unique Arctic lands.

- Bring the basics of Arctic tourism under regulatory control in order to furnish all parties directly or indirectly involved in the tourist activities with a correct general understanding of the term in question.

\section{ACKNOWLEDGMENTS}

The study was carried out with the financial support of the Russian Foundation for basic research (RFBR) in the framework of the scientific project No 18-29-15055 "Development of the legal model of the international scientific and technical collaboration in the field of complex Arctic study". 


\section{REFERENCES}

1. Arctic Region Policy: National Security Presidential Directive and Homeland Security Presidential Directive, NSPD66/HSPD-25. January 9, 2009. Retrieved from https://fas.org/irp/offdocs/nspd/nspd-66.htm

2. Arctic tourism development prospects. National Tourist Union, 2018. Retrieved from https://rusunion.com/perspektivyrazvitija-arkticheskogo-turizmal

3. Canada's Northern Strategy: Our North, Our Heritage, Our Future, 2009. Retrieved from https://polarconnection.org/canadas-northern-strategy-north-heritage-future/

4. Chandra, Geetanjali Ramesh. "Halal tourism; a new goldmine for tourism." International Journal of Business Management \& Research 4.6 (2014): 45-62.

5. Decree of the President of the Russian Federation No.296 as of May 02, 2014 "On the Land Territories of the Russian Federation Arctic Zone". Official Internet portal of legal information. http://pravo.gov.ru/proxy/ips/?docbody=\&nd=102349446\&intelsearch

6. Development Strategy of the Arctic Zone of the Russian Federation and National Security for the Period up to 2020. Approved by the Russian Federation President in 2013. Russian Federation Government. Retrieved from http://government.ru/docs/22846/

7. Khan, Omar Fayaz, and Mohammad Sajid Kirmani. "Seven Key Factors of 2002 National Tourism Policy-An Empirical Study of Kashmir." International Journal of Economics, Commerce and Research, 8 (3) (2018): 1-8.

8. Eagan, K. Global warming contributes to iceberg tourism. Tourism review news, Jul 1, 2019. Retrieved from https://www.tourism-review.com/iceberg-tourism-booming-in-canada-news11121

9. Fes, N. Chinese tourists traveling to the Russian Arctic. Tourism review news, Jan 22, 2018. Retrieved from https://www.tourism-review.com/chinese-tourists-attracted-by-the-russian-arctic-news 10449

10. Chand, Mohinder., and Dahiya. Ashish. "The impact of service quality on tourist satisfaction and loyalty in Indian tour operation industry." International Journal of Sales \& Marketing Management Research and Development (IJSMMRD) 4.5 (2014): 1-14.

11. Finland's Strategy for the Arctic Region, August 2013. Retrieved from http://vnk.fi/documents/10616/334509/Arktinen+strategia+2013+en.pdf/6b6fb723-40ec-4c17-b286-5b5910fbecf4

12. Fundamentals of the Russian Federation State Policy in the Arctic until 2020 and for a Further Perspective. Approved by the Russian Federation President on September 18, 2008, No. Пp-1969. Rossiyskaya Gazeta 4877 (03.27.2009).

13. Rao, V., and R. Choudhury. "A study of the factors influencing customer satisfaction in medical tourism in India." International Journal of Business and General Management 6.5 (2017): 7-22.

14. Geographic Encyclopedia. Arctic. $\quad$ (n.d.). Retrieved from http://dic.academic.ru/dic.nsf/enc_geo/584/\%D0\%90\%D1\%80\%D0\%BA\%D1\%82\%D0\%B8\%D0\%BA\%D0\%BO

15. Ísland 2020 - sókn fyrir atvinnulíf og samfélag. Pekking, sjálfbarni, velferð [Iceland 2020 - an effort for business and society. Knowledge, sustainability, well-being]. Reykjavík: Forsatisráðuneytið, 2011. Retrieved from https://www.forsaetisraduneyti.is/media/Skyrslur/island2020.pdf

16. Linking tourism and conservation in the Arctic, 2016. Retrieved from http://www.ltandc.org/wwf-linking-tourism-andconservation-in-the-arctic-guidelines-still-valid-and-alivel 
17. Lukin, Y.F. Arctic tourism: regional rankings, opportunities and threats. Arctic and North 23 (2016) 96-123.

18. Maher, P., Hillmer-Pegram, K.C., Gelter, H., Hovgaard, G., Huii, J.S., Jóhannesson, G.T., Karlsdóttir, A., Rantala, O., Pashkevich, A. Arctic Tourism: Realities \& Possibilities. Arctic Poral, Arctic Yearbook 2014. Retrieved from https://arcticyearbook.com/images/yearbook/2014/Scholarly_Papers/15.Maher.pdf

19. Orlova, V.S. Arctic tourism - an innovative impulse for the development of the European North. Intellect. Innovations. Investments 4 (2017) 40-43.

20. Sweden's Arctic strategy, May 2011. Retrieved from http://www.government.se/country-and-regionalstrategies/2011/10/swedens-strategy-for-the-arctic-region

21. The Constitution of Finland dated November 06, 1999 (Article 17). World Constitutions. http://worldconstitutions.ru/?p=139

22. The Constitution of the Kingdom of Norway dated May 17, 1814 (Article 11la). World Constitutions. http://worldconstitutions. $r u / ?=142 \&$ page $=2$

23. The Constitution of the Russian Federation dated December 12, 1993 (Article 69). Official Internet portal of legal information. http://pravo.gov.ru/proxy/ips/?docbody=\&nd=102027595\&intelsearch

24. The Kingdom of Denmark's Strategy for the Arctic 2011-2020, August 2011. Retrieved from usa.um.dk/en/ /media/USA/Washington/Arctic_strategy.pdf

25. The Norwegian Government's High North Strategy, December $2006 . \quad$ Retrieved from https://www.regjeringen.no/globalassets/upload/UD/Vedlegg/strategien.pdf 

